\title{
How to date a dragonfly: Fossil calibrations for odonates
}

\author{
Manpreet Kaur Kohli, Jessica L. Ware, and Günter Bechly
}

\begin{abstract}
Molecular data along with fossils are being used increasingly to recover time-calibrated phylogenetic trees. Recently there have been manuscripts that have used divergence dating to understand evolutionary history of certain clades within Odonata (dragonflies and damselflies), yet the number of such articles is still low. We examined the Odonata fossil record and made a list of fossils that can be used for divergence time analysis. In this manuscript we provide a detailed review of the known crown group fossils for the order Odonata and nine nodes within this clade: Zygoptera, Epiprocta, Anisoptera, Aeshnidae, Gomphidae, Cavilabiata, Macromiidae, Corduliidae, and Libellulidae.
\end{abstract}

Manpreet Kaur Kohli. Rutgers University, 195 University Ave, Newark, NJ 07102, USA. mkk24@njit.edu Jessica L. Ware. Rutgers University, 195 University Ave, Newark, NJ 07102, USA. jware@amnh.org Günter Bechly. Department of Paleontology, State Museum of Natural History, Rosenstein 1, 70191 Stuttgart, Germany. guenter.bechly@smns-bw.de (corresponding author)

Keywords: Odonata; Dragonflies; Anisoptera; Crown group fossils; Divergence time estimation

\section{INTRODUCTION}

The fossil record suggests that modern Odonata arose by the Triassic, with Anisoptera having originated at least in the Jurassic. The earliest stem group representatives of dragonflies and damselflies appear in the fossil record in the earliest Pennsylvanian (Namurian). The most wellknown group of this time period were the giant protodonates of the order Meganisoptera (Grimaldi, 2005). Meganisoptera are also known as the "griffenflies". These remarkable stem lineages are characterized by their large wingspans and dense wing venation. Along with Meganisoptera other stem group representatives of odonates existed in the late Carboniferous. Some of these were closely related to modern Odonata. For example, the protozygopterous genera Bechlya (307 Ma) and Luiseia (299 Ma) (Jarzembowski and Nel, 2002; Nel et al., 2012), already had typical odonate wing venational characters like the pterostigma, nodus, and discoidal cell. However,

PE Article Number: 19.1.1FC

Copyright: Palaeontological Association March 2016

Submission: 1 June 2015. Acceptance: 24 February 2016

Kohli, Manpreet Kaur, Ware, Jessica L., and Bechly, Günter. 2016. How to date a dragonfly: Fossil calibrations for odonates.

Palaeontologia Electronica 19.1.1FC: 1-14

palaeo-electronica.org/content/fc-8

Calibrations published in the Fossil Calibration Series are accessioned into the Fossil Calibration Database (www.fossilcalibrations.org). The Database is a dynamic tool for finding up-to-date calibrations, and calibration data will be updated and annotated as interpretations change. In contrast, the Fossil Calibration papers are a permanent published record of the information on which the calibrations were originally based. Please refer to the Database for the latest data. 
crown group Odonata are much younger, having diverged sometime after the late Triassic and greatly diversified during the Cretaceous according to the fossil evidence.

Divergence time dating is a useful method for understanding the chronology of relationships and patterns seen in a molecular phylogeny. Fossils, used as maximum and minimum bound for calibrations, are an important part of divergence time estimation (Inoue et al., 2010). However, the accuracy of a time-calibrated phylogeny is heavily dependent on the choice of the fossils (Sauquet et al., 2012). Incorrect fossil choice (for example choosing a stem fossil as a calibration for a crown node) can lead to erroneously and inadequate dates (Joyce et al., 2013, Dos Reis and Yang, 2013).

In the last two decades many studies have presented relationships among different families of Anisoptera, the dragonflies, based on morphological and molecular evidence (e.g., Carle, 1995; Bechly, 1996; Lohmann, 1996; Trueman, 1996; Bechly et al., 1998; Kambhampati and Charlton, 1999; Misof et al., 2001; Carle and Kjer, 2002; Rehn, 2003; Saux et al., 2003; Pfau, 2005; Hasegawa and Kasuya, 2006; Hovmöller, 2006; Ware et al., 2007; Bybee, 2008; Bybee et al., 2008; Carle et al., 2008; Fleck et al., 2008; Ware et al., 2008; Letsch et al., 2009; Dumont et al., 2010; Davis et al., 2011; Fleck, 2011; Blanke et al., 2013), the most recent being Carle et al. (2015), but the number of studies looking at divergence times in this group are still relatively low. Most of these studies have recovered time-calibrated phylogenies at a family level (Ware et al., 2014 [Petaluridae], Ware et al., 2008 [Libelluloidea], Ware et al., 2009 [Synthemistidae]), but not for the complete suborder Anisoptera (the dragonflies). Dates recovered for some families are not always in agreement with the fossil record (Fleck et al., 2009; Davis et al., 2011). In this paper we bring together a thorough examination of the Odonata fossil record with vetted calibration points for anisopteran nodes to be used in divergence time estimation. We provide a list of 10 meticulously chosen Odonata fossils, which follow the best practices for justifying fossil calibrations as outlined by Parham et al. (2012). The crown groups used in this manuscript are based on the most recent phylogeny-based classification of Odonata from Carle et al. (2015).

\section{METHODS}

\section{Calibrating Nodes}

Our calibrations pertain to nodes representing the crown clades, which include the most recent common ancestor and all its Recent descendants, extinct or extant. Consequently, fossils used for calibrating the crown group nodes must possess at least one convincing synapomorphy that supports nesting within the crown clade. Wing venation characters are used most frequently for establishing these synapomorphies. A detailed diagram of the anisopteran wing venation can be seen in Figure 1 (see Appendix 1 for venerational terminology). Calibrations reported here will provide a lower limit for the age of each taxon. Ten nodes have been calibrated in this paper, including the Odonata-Ephemeroptera split, all three recent suborders in Odonata, and the five Recent families of Anisoptera that have fossil crown group representatives.

\section{CROWN ODONATA}

Node Calibrated: (1) Crown Odonata. This node represents the order crown Odonata (Zygoptera + Anisozygoptera + Anisoptera).

Species. Triassolestodes asiaticus (Triassolestidae) Pritykina, 1981

Specimen. PIN 2240/1783 at Paleontological Institute of the Academy of Science of Russia, Moscow, Russia. This fossil is a hind wing representing the holotype of Triassolestodes asiaticus.

Phylogenetic Justification. Triassolestodes was attributed by $\mathrm{Nel}$ et al. (1993) to the paraphyletic grade "Anisozygoptera", but subsequently shown to belong to Triassolestidae (Epiprocta: Isophlebioptera) by Bechly (1997) and Nel et al. (2002). The latter authors redescribed the holotype, listed synapomorphies (like AA and CuP and MP and CuA are partly fused basal of the arculus in the hind wing) in support of the attribution, and also provided a parsimony-based analysis, which confirmed Triassolestodes fell within the Isophlebioptera-Triassolestidae clade.

Minimum Age. $237 \mathrm{Ma}$.

Age Justification. The type location of this fossil is Dzhayloucho, near Madygen, south of Fergana Valley, Kyrgyzstan. Found in Upper Triassic, Ladinian-Carnian of the Madygen Formation. The attribution of this fossil to Ladinian (242-237 Ma) rather than Carnian (237-227 Ma) by Shcherbakov (2008) is based on the megaflora (Shcherbakov, 2008), which is significantly different and more primitive than that of other Carnian localities (e.g., 

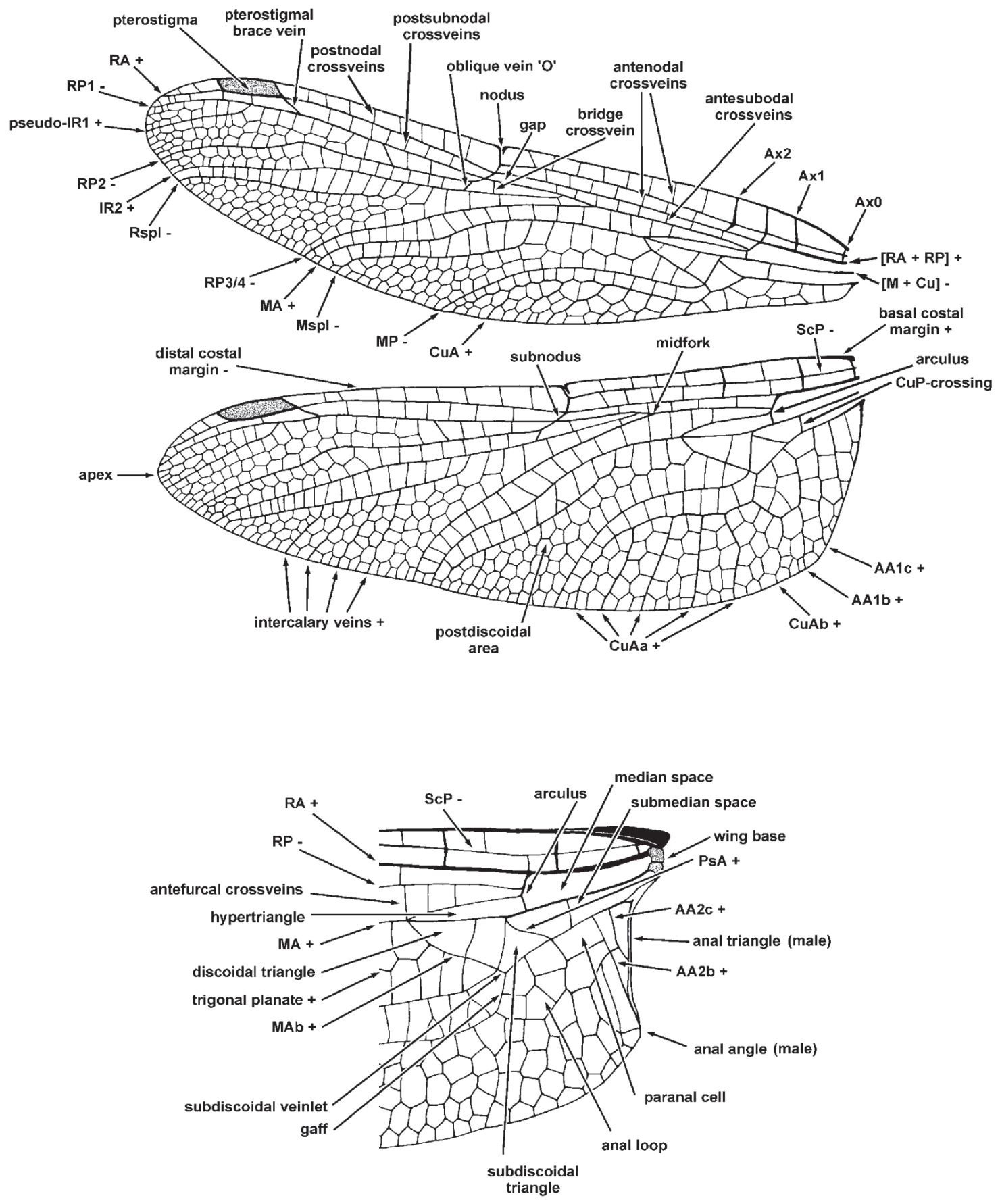

FIGURE 1. Wing venation of Anisoptera (after Bechly et al., 2001) (details for the abbreviations in Appendix 1).

Ipswich Insect Beds in Australia or Molteno Formation in South Africa).

Discussion. This fossil has not yet been used in molecular divergence time analyses, but will be useful in studies exploring divergence between Ephemeroptera and Odonata. Several other fossil Triassolestidae have been described from the same age: Mesophlebia antinodalis Tillyard, 1916 and Triassolestes epiophlebioides Tillyard, 1918 (227 Ma, Carnian, Ipswich, Australia), Triassoneura andersoni Riek, 1976 (Carnian, Molteno Formation, South Africa), and Triassothemis mendozensis Carpenter, 1960 (Carnian, Argentina). Two slightly younger but still undescribed fossil Isophlebioptera-Isophlebioidea have been found in the Carnian (232 Ma) of Bavaria, and the Car- 
nian (230 Ma) of Steigerwald in Germany (Bechly, 2015). All these fossil Isophlebioptera also provide a minimum age for the stem group clade Epiprocta (and thus indirectly for stem group Zygoptera), because Isophlebioptera is more closely related to Epiophlebiidae + Anisoptera than to Zygoptera.

\section{CROWN ZYGOPTERA}

Node Calibrated: (2) Crown Zygoptera. This node represents the suborder crown Zygoptera (damselflies).

Species. Mersituria ludmilae (Hemiphlebiidae) Vasilenko, 2005

Specimen. Part and counterpart of incomplete forewing, PIN no. 4626/462 at Paleontological Institute of the Academy of Science of Russia, Moscow, Russia.

Phylogenetic Justification. Several wing characters support the attribution of this fossil to Hemiphlebiidae, close to the Cretaceous genus Parahemiphlebia, such as tiny size with few cells in the wing venation, basally open discoidal cell in forewings, non-aligned postnodal and postsubnodal crossveins, and the kink of RP1 at the stigmal brace vein.

Minimum Age. $132.9 \mathrm{Ma}$.

Age Justification. Found in Doronino Formation, Chernovskaya transitional sequence, Upper Jurassic (late Malm, Tithonian) or Lower Cretaceous (early Neocomian, Valanginian), Chernovskie Kopi, left bank of Ingoda River, $18 \mathrm{~km}$ southwest of Chita city, Chita Region, Chita District, Transbaikalian Siberia, Russia (Vasilenko, 2005). The dating is based on geological data and the stratigraphical position of the sediments (Sinitza, 1995; Sukatsheva and Vassilenko, 2013). The provided absolute age for Tithonian-Valanginian is based on the most recent International Chronostratigraphic Chart v2013/01 (Cohen et al., 2013).

Discussion. Further Upper Jurassic Hemiphlebiidae have recently been discovered in the silificied limestone of Painten (uppermost Kimmeridgian, $153 \mathrm{Ma}$ ) and the Solnhofen lithographic limestones (150 Ma) from Bavaria in Germany (Bechly, unpublished data), but they are still unpublished. Therefore, these fossils are not considered at this time.

\section{CROWN EPIPROCTA}

Node Calibrated: (3) Crown Epiprocta. This node represents crown Epiprocta (Anisozygoptera + Anisoptera).

Species. Liassophlebia sp. (Liassophlebiidae) Tillyard, 1925
Specimen. Incomplete right hind wing of a female Liassophlebia sp. with collection number TUCIP-In192 in collection of Prof. Carsten Brauckmann at the Technische Universität Clausthal (Paläontologie) in Clausthal-Zellerfeld, Germany.

Phylogenetic Justification. The wing venation of this fossil is nearly identical to other fossils of the genus Liassophlebia and shares the following synapomorphies with Heterophlebioptera and Heterophlebioidea (Nel et al., 1993; Bechly, 1996): unique unicellular anal loop, which lies beneath the subdiscoidal cell and is ventrally closed by CuAb that is parallel to $A A$ and thus directed towards the wing base instead of the posterior wing margin; subdiscoidal cell of the hind wing with a convex curved or angulated posterior margin; antenodal crossveins between costal margin and ScP suppressed distal of ax2; IR2 arising on RP3/4. The attribution to the stem group of Anisoptera is well established by the unique synapomorphy of the shape of the hind wing discoidal cell, which foreshadows the anisopterid division into hypertriangle and triangle (only sometimes lacking the dividing crossvein).

Minimum Age. 199.3 Ma.

Age Justification. Found in clay lenses in sandy sediments ("Pflanzensandstein"), Bayreuth Formation, sand pit at Pechgraben (district Kulmbach) near Bayreuth, Northern Bavaria, Germany. Lower Jurassic, Liassic alpha 1 (Rhaeto-Liassic), lower Hettangian, $200 \mathrm{Ma}$ (Cohen et al., 2013). The attribution to the Rhaeto-Liassic is established by the stratigraphic position of the Bayreuth Formation between well-dated Keuper sediments and the Gryphaeensandstein Formation (Bloos et al., 2005), and by plant index fossils (Weber, 1968).

Discussion. This fossil is not yet assigned to a species and was only figured in the unpublished Ph.D. thesis of the author (Bechly, 1999, text-figure 138). Therefore, we here provide a drawing of the wing venation (Figure 2). Fully described specimens of Liassophlebia have been found in only slightly younger sediments of the Lower Jurassic (lower Pliensbachian, Carixian Substage, ca. 190 $\mathrm{Ma}$ ) of Charmouth, England (Nel et al., 1993). The much more advanced Liassogomphidae are known from the Toarcian (180 Ma) of several localities in middle Europe (Nel et al., 1993).

\section{CROWN ANISOPTERA}

Node Calibrated: (4) Crown Anisoptera. This node represents crown Anisoptera (dragonflies). Species. Sinacymatophlebia mongolica (Cymatophlebiidae) Nel and Huang, 2009 


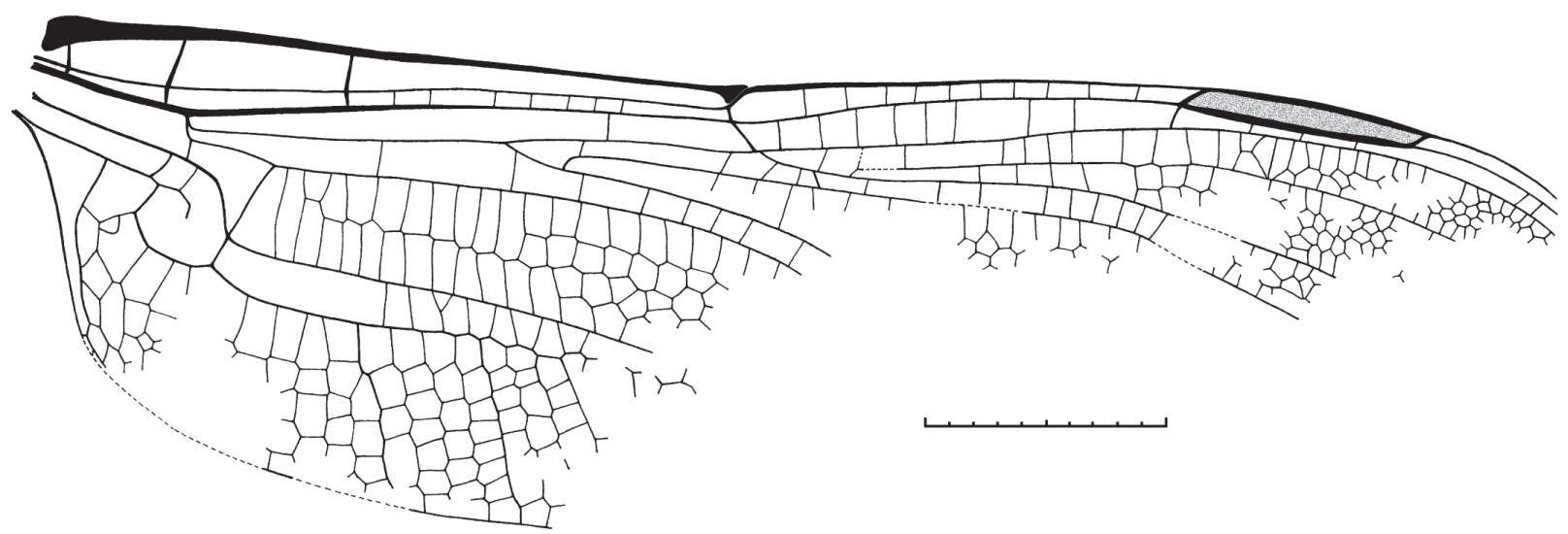

FIGURE 2. Wing venation of Liassophlebia sp., specimen TUCIP In 192, from the Liassic alpha of Pechgraben in Germany (Bechly, 1999) (Scale equals $10 \mathrm{~mm}$ )

Specimen. NIGP 148312 (Nanjing Institute of Geology and Palaeontology, China): hind wing of male, holotype of Sinacymatophlebia mongolica.

Phylogenetic Justification. The phylogenetic relationship of this fossil with Aeshnidae and hence Anisoptera is strongly supported by many wing venational synapomorphies (Bechly et al., 2001; Nel and Huang, 2009). These include: the presence of Rsp1 vein, RP1 and RP2 basally parallel up to the pterostigma, and RP3/4 and MA undulating.

Minimum Age. $168 \mathrm{Ma}$.

Age Justification. Found in Middle Jurassic Jiulongshan Formation (= Haifanggou Formation) near Daohugou village, Wuhua township, Ningcheng county, Chifeng city, Inner Mongolia, northeast China. The Daohugou-Biota, resting on the Jiulongshan Formation, has been dated with SHRIMP U-Pb zircon age of 168-152 Ma, giving a minimum age for Jiulongshan Formation of $168 \mathrm{Ma}$ (Liu et al., 2006). There is debate about the age of the Jiulongshan Formation, as radioisotopic studies have not been congruent (Liu et al., 2012). However, because the Daohugou Formation overlies the Jiulonshan formation, we can conservatively use the age range of the former to provide a minimum age as $168 \mathrm{Ma}$ for the calibrating fossil.

Discussion. This fossil calibrates the crown group node Anisoptera (Figure 3), which we are considering to include modern families of Anisoptera but not the Liassic stem group families Henrotayiidae and Liassogomphidae (Fleck et al., 2003; Davis et al., 2011). This fossil also calibrates the crown group node for Aeshnoidea (Austropetaliidae + Aeshnidae), a well-supported clade called Aeshnoptera by Bechly et al. (2001). This has not yet been used in molecular estimates. Ware et al. (2007) and
Ware (2008) set the maximum age of Anisoptera to be $250 \mathrm{Ma}$, with a minimum age for Anisoptera of 144 and $120 \mathrm{Ma}$, respectively. The current fossil calibration will provide more accuracy and precision at the root of the dragonfly tree.

$\mathrm{Nel}$ and Huang (2009) placed this species in Cymatophlebiidae based on various alleged synapomorphies, such as the presence of undulating IR2 that is parallel to RP2 and RP3/4 and MA being more strongly undulating compared to other families. We consider the original attribution of Sinacymatophlebia to Cymatophlebiidae to be erroneous and assert that it rather belongs to Paracymatophlebiidae, because it shares all synapomorphies of Paracymatophlebiidae and only differs from this extinct family in the plesiomorphic presence of a second distal lestine oblique vein. The strongly undulating RP3/4 and MA are not only shared with Cymatophlebiidae but also with Paracymatophlebiidae. Contrary to Nel and Huang (2009, p. 203), the published figures of Sinacymatophlebia show that it lacks the main synapomorphy of Cymatophlebiidae, namely the undulating course of IR2 parallel to the undulating RP2. As stated by Nel and Huang (2009), Sinocymatophlebia differs from Cymatophlebioidea (Cymatophlebiidae + Rudiaeschnidae) by the plesiomorphic presence of only two rows of cells between IR2 and Rspl. This latter character state is again shared with Paracymatophlebiidae. According to Bechly et al. (2001), Paracymatophlebiidae is even more closely related to Aeshnidae than Cymatophlebiidae, sharing a larger set of synapomorphies. An attribution of Sinacymatophlebia to Paracymatophlebiidae rather than Cymatophlebiidae would thus not affect the calibration of this node and Sinacymatophlebia 


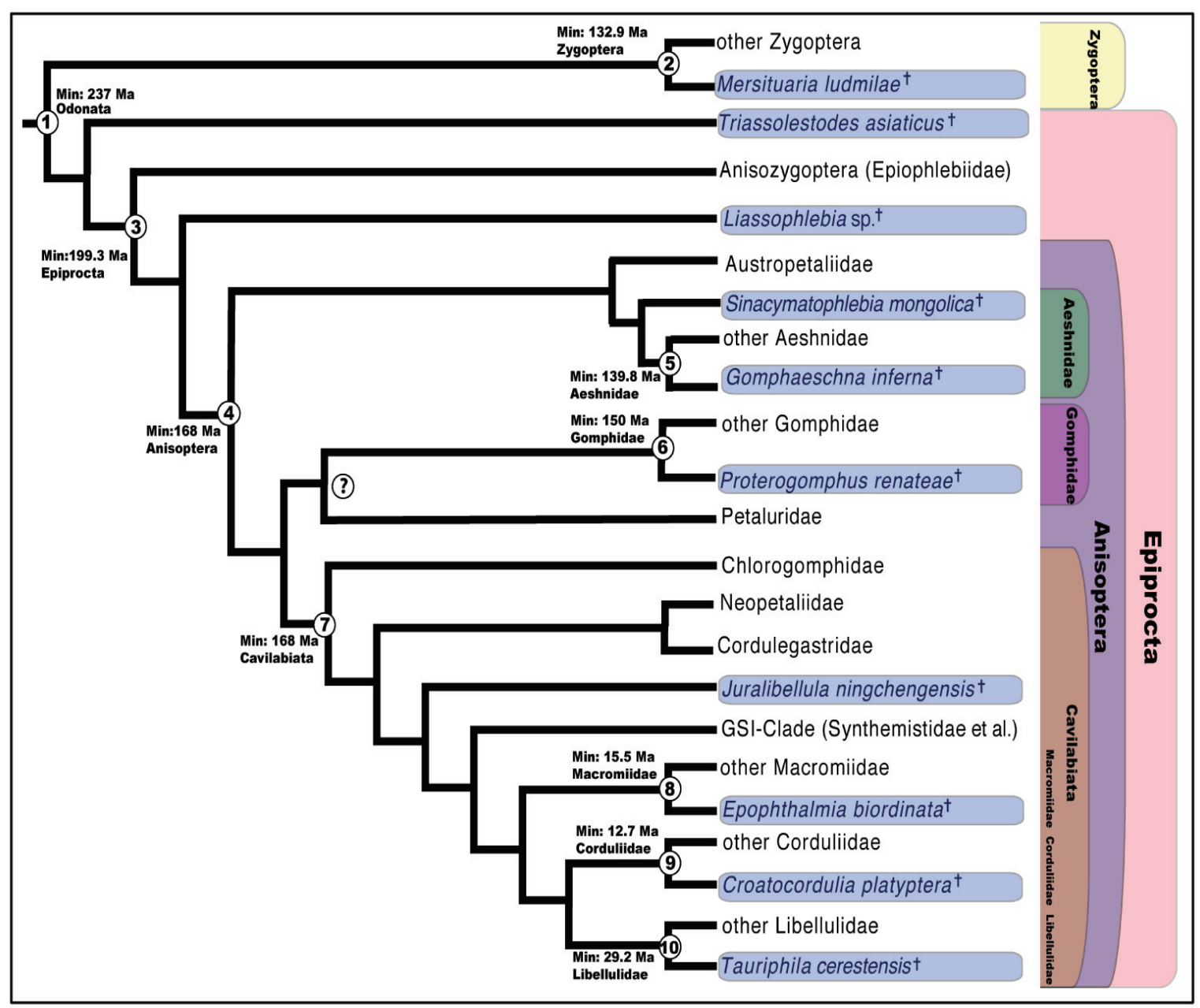

FIGURE 3. A cladogram of Odonata (adapted from Carle et al., 2015) showing the phylogenetic relationships among Anisopteran families. The species highlighted in blue are the crown group fossils discussed in this manuscript. Node numbers are listed in the order in which they are discussed in the manuscript. Node ages indicate the minimum age of the crown fossil used. The question mark indicates weak support for the node Petaluridae + Gomphidae (see Carle et al., 2015 for more details). Extinct species are indicated by a dagger. Note: nodes 2, 5, 6, 8, 9, and 10 are drawn for simplicity, but these fossil taxa may be nested deep within the family to which they are assigned. The fossils shown in the tree are not sister to the rest of the members of the family.

mongolica represents the oldest crown group Anisoptera under either scenario.

\section{CROWN AESHNIDAE}

Node Calibrated: (5) Crown Aeshnidae. This node represents crown Aeshnidae.

Species. Gomphaeschna inferna (Gomphaeschninae) Pritykina, 1977

Specimen. Hind wing without base, PIN 1989/ 1808 Paleontological Institute of the Academy of Science of Russia, Moscow, Russia.

Phylogenetic Justification. This fossil preserves the all the synapomorphies of the subfamily Gomphaeschninae: lack of crossveins in the antesub- nodal area between RA and RP, no accessory cubitoanal crossveins in the submedian space between CuP-crossing and PsA and the discoidal triangle only divided into two cells by a single crossvein (Bechly et al., 2001).

Minimum Age. 139.8 Ma.

Age Justification. Found in Zara Formation, Zazinsk series at Baissa near the uppermost course of Vitim River, Transbaikals, Eravninsk region, Buryat Republic (Tyumen), Russia. The Zara Formation is Berriasian (145.0-139.8 Ma; Lower Cretaceous) in age, according to (Cohen et al., 2013). Thus the minimum age of the Berriasian is used for the calibration. 
Discussion. This fossil has not yet been used in a molecular divergence estimation. Although the specimen has this been tested phylogenetically for its inclusion within the genus Gomphaeschna, evidence from synapomorphies supports its use as a calibration for crown Aeshnidae. The oldest fossil record of the basal aeshnid subfamily Gomphaeschninae was chosen to calibrate this node. Baissaeschna prisca Pritykina, 1977, belonging to the Allopetaliinae (Bechly et al., 2001), has been found in the same strata of the Zara formation and hence provides additional support for the calibration of this node. Gomphaeschna? sibirica, was described by Bechly et al. (2001) from a Siberian locality of similar Lower Cretaceous age.

\section{CROWN GOMPHIDAE}

Node Calibrated: (6) Crown Gomphidae. This node represents crown Gomphidae.

Species. Proterogomphus renateae (Proterogomphinae) Bechly et al., 1998

Specimen. Specimen no. 6D in collection of $D$. Kümpel, Wuppertal, Germany: a male exoskeleton (complete specimen missing one wing). This type specimen shall be donated or inherited to Staatliches Museum für Naturkunde Stuttgart (SMNS), Stuttgart, Germany.

Phylogenetic Justification. Bechly et al. (1998), Bechly (1998), and Vernoux et al. (2010) established the phylogenetic position of Proterogomphidae within the crown group of Recent Gomphidae, as closest relatives of the subfamily Hageniinae. This position is supported by several synapomorphies, like hind wing triangles with angulate distal side and trigonal planate (posttrigonal sector), hind wings with less than 5 antefurcal crossveins, and branching of RP at midfork symmetrical.

Minimum Age. $150 \mathrm{Ma}$.

Age Justification. Found in Solnhofen limestones of Bavaria, Germany. These limestones are lower Tithonian (Upper Jurassic) in age. Specifically, the Malm zeta $2 \mathrm{~b}$, Hybonotum zone has a minimum age of $150 \mathrm{Ma}$ (Schweigert, 2007).

Discussion. This has not yet been used in phylogenetic analyses or divergence time estimation. Apart from Proterogomphus renateae, all other species of Proterogomphidae are found in Lower Cretaceous strata (Bechly et al., 1998; Bechly, 2010; Vernoux et al., 2010). Additional crown group Gomphidae are known from the Lower Cretaceous (upper Aptian, ca. $115 \mathrm{Ma}$ ) Crato Formation of Brazil, including Cratolindenia and Cratohagenius (Bechly, 2000; Bechly, 2010).

\section{CROWN CAVILABIATA (LIBELLULOIDEA SENSU LATO)}

Node Calibrated: (7) Crown Cavilabiata. This node represents the suborder Cavilabiata.

Species. Juralibellula ningchengensis (Juralibelulidae) Huang and Nel, 2007

Specimen. NIGP 143439 (Nanjing Institute of Geology and Palaeontology, China): a thorax with four wings.

Phylogenetic Justification. This species was demonstrated by Huang and $\mathrm{Nel}$ (2007) to be nested within Cavilabiata as sister group to Neobrachystigmata. It shares the main wing venational apomorphies of Cavilabiata: distal part of antesubnodal area free of crossveins ("cordulegastrid gap"), basal part of CuA ("gaff") before its branching distinctly prolonged in hind wing, RP $3 / 4$ and MA slightly undulating; pterostigmata not parallel sided (distal side more oblique than basal side), and rather stout with length less than eight times width, forewing nodus shifted distinctly distal of midwing position; hind wing $\mathrm{CuAa}$ shortened, with only five posterior branches, anal loop elongated and enlarged with more than five cells. Furthermore, it shares several synapomorphies with more advanced Cavilabiata, which are absent in Cordulegastridae + Neopetaliidae: Pterostigmata short covering only 1-3 cells, distal area between RP2 and IR2 widened with at least two rows of cells, basal area between MP and CuA widened with at least two rows of cells in hind wing, terminal branch of CuAa secondarily branched on CuA.

Minimum Age. $168 \mathrm{Ma}$.

Age Justification. Found in Middle Jurassic Jiulongshan Formation (= Haifanggou Formation) near Daohugou village, Wuhua township, Ningcheng county, Chifeng city, Inner Mongolia, northeast China. As discussed above in the Anisoptera calibration age justification, the 168 Ma minimum age is derived from the age range of the overlying Daohugou Formation.

Discussion. According to Huang and Nel (2007) Juralibellula is relatively advanced and appears to be nested well within Cavilabiata, suggesting great antiquity for the clade as a whole. Cavilabiata is a well-supported node by both morphology and molecular data (e.g., (Misof et al., 2001; Fleck et al., 2008; Letsch et al., 2009; Blanke et al., 2013). The presence of the apomorphic spoon-shaped labial mask supports the monophyly of this group. This group formerly referred to as Libelluloidea includes families: Chlorogomphidae, Neopetallidae, Cordulegastridae, Macromiidae, Cordullidae, Libellulidae and GSI (sensu Ware et al., 2007). 
Molecular divergence time estimates by Ware et al. (2007) and (2008) suggest a Cretaceous age for the Cavilabiata clade.

\section{CROWN MACROMIIDAE}

Node Calibrated: (8) Crown Macromiidae. This node represents the crown Macromiidae.

Species. Epophthalmia biordinata (Macromiidae) Lewis, 1969

Specimen. University of Colorado Boulder. Holotype specimen No. UCM 28198: hind wing.

Phylogenetic Justification. This is a fossil that is assigned to the genus Epophthalmia, which has been recovered by Ware and Ballare (unpublished data) within the family Macromiidae. Synapomorphies supporting this assigning of the fossil wing include the presence of more antenodal crossveins than Macromia, or Didymops, which are all sister taxa to Epophthalmia. Additionally, the anal loop in this fossil more closely resembles to Epophthalmia than any of the other members of Macromiidae (Lewis, 1969). Nel and Paicheler (1994) considered the attribution to the recent genus Epophthalmia as probable.

Minimum Age. $15.5 \mathrm{Ma}$.

Age Justification. Found in Latah Formation at Marshall Creek, Spokane, Washington, USA. Age estimates for the Latah Formation span the Burdigalian-Langhian-Serravallian (Miocene). Based on an electron microprobe analysis of $\mathrm{Fe}$ and $\mathrm{Ca}$ content in ash samples, Nash and Perkins (2012) correlated the previously undated Latah Formation to the well-dated lower Bully Creek Formation (also dated by electron microprobe analysis), and thus establish an absolute age of 15.8-15.5 Ma (Langhian).

Discussion. Two other fossil macromiid species, Epophthalmia zotheca Zhang, 1989 and Macromia pilifera Lin, 1982 (attributed to Macromia by Zhang et al., 1994) as well as Macromia sp. larvae (Zhang, 1989) have been described from the early middle Miocene of Shanwang in the Shandong Province of China.

\section{CROWN CORDULIIDAE}

Node Calibrated: (9) Crown Corduliidae. This node represents the crown Corduliidae.

Species. Croatocordulia platyptera (Corduliidae) de Charpentier, 1843

Specimen. The holotype specimen (described without collection number), a male dragonfly specimen preserving three wings and body fragments, was loaned to Charpentier by the famous German botanist Heinrich Göppert (Breslau). It is lost according to Kiauta (1969). Our inquiry showed that the fossil is not preserved at the University of Wrockaw in Poland, where most of the remaining specimens of Göppert's private fossil collection are deposited in the Geological Museum and the Institute of Evolutionary Biology and Ecology). It is also not in the Radoboj collection of Oswald Heer at the ETH Zürich (Switzerland), even though Heer (1849) had examined and redescribed this fossil specimen. A figure of this fossil can be found in Heer (1849), on page 5 and figure number $3 b$.

Phylogenetic Justification. Kiauta (1969) suggested a close relationship of this fossil genus with the recent Corduliid genera Cordulia, Dorocordulia, and Somatochlora, based on a comparison of wing venational characters. This attribution was followed by Nel and Paicheler (1994). Several synapomorphies confirm an attribution to Corduliidae + Libellulidae, like the hind wings with triangle recessed to arculus and a boot-shaped anal loop with midrib. The presence of an anal triangle and anal angle excludes a position in Libellulidae. The presence of only one crossvein beneath the pterostigma, as well as the phenetic similarity of the venation pattern in both pairs of wings, confirms an attribution to Corduliidae.

Minimum Age. 12.7 Ma.

Age Justification. Found in Radoboj (Radoboy) near Krapina, north of Zagreb in Croatia, late middle Miocene, Serravalian/early Sarmatian, lacustrine limestone. According to Mlíkovský (1997), the Radoboj site was specified as Sarmatian, which corresponds to the younger part of the middle Miocene, or to the micromammal Neogene zones MN 7-8. This author mentioned that micropaleontological research of the middle Miocene deposits around Krapina dated two of the localities (Lopatica and Gornja Šemnica) as early Sarmatian, and one (Frug) in the nannoplankton zones 6-7. Mlíkovský (1997) considered it as probable from this context that the classical Radoboj site belongs in micromammal zone $\mathrm{MN} 7$, which lasts from 14.8-12.7 Ma according to Steininger et al. (1996). Discussion. Two older alleged crown group Corduliidae have been described: Stenogomphus? scudderi was described by Cockerell (1921) from the middle Eocene Green River Formation from Green River, Wyoming (USA), and Stenogomphus carletoni was described by Scudder (1892) from the late Eocene Florissant Formation of Colorado (USA). Unfortunately, the attribution of Stenogomphus to Corduliidae is dubious and would need a thorough revision of the type material (Nel and Pai- 
cheler, 1994). Ris (1910) considered Stenogomphus carletoni to be closely related to the recent genera Neurocordulia, Platycordulia, and Aeschnosoma, which was considered by $\mathrm{Nel}$ and Paicheler (1994) as the most probable hypothesis. If this attribution could be confirmed by a revision of the holotype, it would extend the minimum age of crown group Corduliidae to the Oligocene.

We did not use Molercordulia karinae from the Palaeocene Moler Formation of Denmark as a calibration point because its attribution to Corduliidae by Bechly (2005) was based on symplesiomorphies. It cannot be ruled out that Molercordulia could be a stem group representative of Corduliidae, a stem group representative of Libellulidae, or even an advanced stem group representative of the clade Corduliidae + Libelulidae.

\section{CROWN LIBELLULIDAE}

Node Calibrated: (10) Crown Libellulidae. This node represents crown Libellulidae.

Species. Tauriphila? cerestensis $\mathrm{Nel}$ and Paicheler, 1993

Specimen. MNHM PE 2014/4 (old no. Od6 coll. Herbert Lutz) at Naturhistorisches Museum in Mainz (Germany): a nearly complete dragonfly.

Phylogenetic Justification. Even though this extant genus has never been included in a phylogenetic analysis based on molecular data, morphological studies suggest that Tauriphila is a libellulid. It shares the unique wing venational apomorphies of the family Libellulidae (e.g., shape of anal loop) and can be attributed to the modern subfamily Pantalinae (= Trameinae) based on the presence of two rows of cells between Rspl and IR2, and the strongly broadened hind wing anal field with numerous small cells basal of anal loop, correlated with a typical triangular shape of hind wings (Davies and Tobin, 1985). The Nel and Paicheler (1993) Tauriphila? fossil meets the synapomorphies for Trameinae (with the exception of flight behavior) and for Tauriphila (last antenodal incomplete, forewing triangle crossed, Mspl distinct, median planate cells forming a single row; Garrison et al., 2006).

Minimum Age. 29.2 Ma.

Age Justification. Found in Céreste, Vaucluse, France. These deposits are upper Rupelian (33.928.1 Ma; Cohen et al., 2013), and can be assigned to the "Stampien supérieur", mammal Paleogene zone MP 24 (Ducreux et al., 1985) which spans 30.2-29.2 Ma (İslamoğlu et al., 2010).
Discussion. Sympetrum bigoti Nel and Papazian, 1985 was described from the latest Oligocene of Aix-en-Provence in France, which confirms the presence of the crown group of Libellulidae in the upper Oligocene. The libellulid Palaeolibellula zherikhini was described from the Upper Cretaceous (Turonian, 93.9-89.8 Ma) of Kazakhstan by Fleck et al. (1999) but we did not use it to calibrate the crown group node Libellulidae because the phylogenetic position of this fossil species within the family Libellulidae is not resolved and it might instead represent a stem libellulid.

\section{CONCLUSION}

Here we have provided the oldest crown fossils for clades Odonata, Zygoptera, Anisoptera, Epiprocta, Aeshnidae, Gomphidae, Macromiidae, Cordullidae, and Libellulidae. However, we lack a crown group fossil record for Epiophlebiidae, Austropetaliidae, Chlorogomphidae, Neopetaliidae, Cordulegastridae, and GSI/Synthemistidae. Molecular ages for the nodes within Odonata are few in number, with only Calopterygoidea (Dumont et al., 2005) Petaluridae (Ware et al., 2014), and Libelluloidea/Cavilabiata (Ware et al., 2008) estimated so far. For Anisoptera, the molecular ages suggest a Cretaceous origin of Cavilabiata. The fossil evidence we present here suggests a minimum age in the mid-Cretaceous Period. We hope researchers will find this manuscript a useful resource, and we look forward to using these current fossil calibrations in future divergence time estimates across anisopteran families and genera.

\section{ACKNOWLEDGEMENTS}

We would like to acknowledge D. Ksepka and J. Parham for inspiring this manuscript, and the support from the Working Group Synthesizing and Databasing Fossil Calibrations: Divergence Dating and Beyond at the National Evolutionary Synthesis Center (NESCent: NSF no. EF-0905606). We also thank all of the Odonata palaeoentomologists working on fossil Odonatoptera. We are also grateful to $\mathrm{H}$. Lutz for information about his fossil collection and for donating the holotype of Tauriphila? cerestensis to the Naturhistorisches Museum in Mainz, to M. Pika-Biolzi for information about the Heer collection at ETH Zürich, and to J. Białek for information about the Goeppert collection at the Geological Museum of the University of Wroclaw. 


\section{REFERENCES}

Bechly, G. 1996. Morphologische Untersuchungen am Flügelgeäder der rezenten Libellen und deren Stammgruppenvertreter (Insecta; Pterygota; Odonata) unter besonderer Berücksichtigung der phylogenetischen Systematik und des Grundplanes der Odonata. Petalura, Special Vol. 2:1-402. (In German)

Bechly, G. 1997. New fossil Odonata from the Upper Triassic of Italy, with a redescription of Italophlebia gervasutti, and a reclassification of Triassic dragonflies. Rivista del Museo Civico di Scienze Naturale E. Caffi, 19:31-70.

Bechly, G. 1998. New fossil dragonflies from the Lower Cretaceous Crato Formation of north-east Brazil (Insecta: Odonata). Stuttgarter Beiträge zur Naturkunde, Series B, 264:1-66.

Bechly, G. 1999. Phylogeny and Systematics of Fossil Dragonflies: (Insecta: Odonatoptera); with Special Reference to Some Mesozoic Outcrops. EberhardKarls-University, Tübingen, Germany.

Bechly, G. 2000. Two new fossil dragonfly species (Insecta: Odonata: Anisoptera: Araripegomphidae and Lindeniidae) from the Crato limestone (Lower Cretaceous, Brazil). Stuttgarter Beiträge zur Naturkunde, Series B, 296:1-16.

Bechly, G. 2005. A New Fossil Dragonfly (Anisoptera: Corduliidae) from the Paleocene Fur Formation (Mo Clay) of Denmark. Staatliches Museum für Naturkunde, Series B, (358):1-7.

Bechly, G. 2010. Additions to the fossil dragonfly fauna from the Lower Cretaceous Crato Formation of Brazil (Insecta: Odonata). Palaeodiversity, 3:11-77.

Bechly, G. 2015. Fossile Libellennachweise aus Deutschland (Odonatoptera). Libellula Supplement, 14:423-464. (In German)

Bechly, G., Nel, A., Martinez-Delclos, X., and Fleck, G. 1998. Four new dragonflies from the Upper Jurassic of Germany and the Lower Cretaceous of Mongolia (Anisoptera: Hemeroscopidae, Sonidae, and Proterogomphidae fam. nov.). Odonatologica, 27:149187.

Bechly, G., Nel, A., Martínez-Declòs, X., Jarzembowski, E.A., Coram, R., Martill, D., Fleck, G., Escuillié, F., Wisshak, M.M., and Maisch, M. 2001. A revision and phylogenetic study of Mesozoic Aeshnoptera, with description of numerous new taxa (Insecta: Odonata: Anisoptera). Neue Paläontologische Abhandlungen, 4:1-219.

Blanke, A., Greve, C., Mokso, R., Beckmann, F., and Misof, B. 2013. An updated phylogeny of Anisoptera including formal convergence analysis of morphological characters. Systematic Entomology, 38:474-490.

Bloos, G., Dietl, G., and Schweigert, G. 2005. Der Jura Süddeutschlands in der Stratigraphischen Tabelle von Deutschland 2002. Newsletters on stratigraphy, 41:1-3. (In German)

Bybee, S.M. 2008. Phylogenetics, Evolution and Systematics of Holodonata with Special Focus on Wing Structure Evolution: Morphological, Molecular and
Fossil Evidence. University of Florida, Gainesville, Florida.

Bybee, S.M., Ogden, T.H., Branham, M.A., and Whiting, M.F. 2008. Molecules, morphology and fossils: a comprehensive approach to odonate phylogeny and the evolution of the odonate wing. Cladistics, 24:477514.

Carle, F.L. 1995. Evolution, taxonomy, and biogeography of ancient Gondwanian libelluloides, with comments on anisopteroid evolution and phylogenetic systematics (Anisoptera: Libelluloidea). Odonatologica, 24:383-424.

Carle, F.L. and Kjer, K.M. 2002. Phylogeny of Libellula Linnaeus (Odonata: Insecta). Zootaxa, 87:1-18.

Carle, F.L., Kjer, K.M., and May, M.L. 2008. Evolution of Odonata, with special reference to Coenagrionoidea (Zygoptera). Arthropod Systematics \& Phylogeny, 66:37-44.

Carle, F.L., Kjer, K.M., and May, M.L. 2015. A molecular phylogeny and classification of Anisoptera (Odonata). Arthropod Systematics \& Phylogeny, 73:281301.

Carpenter, F.M. 1960. A Triassic Odonate from Argentina. Psyche, 67:71-75.

Cockerell, T.D. 1921. Some Eocene insects from Colorado and Wyoming. Proceedings of the United States National Museum, 59:29-39.

Cohen, K.M., Finney, S., and Gibbard, P.L. 2013. International Chronostratigraphic Chart. International Commission on Stratigraphy.

Davies, D.A.L. and Tobin, P. 1985. The Dragonflies of the World: A Systematic List of Extant Species of Odonata. Vol. 2. Anisoptera. Societas Internationalis Odonatologica Series: Rapid Communication (Supplements), Utrecht.

Davis, R.B., Nicholson, D.B., Saunders, E.L., and Mayhew, P.J. 2011. Fossil gaps inferred from phylogenies alter the apparent nature of diversification in dragonflies and their relatives. BMC Evolutionary Biology, $11: 252$.

de Charpentier, T. 1843. Über einige fossile Insecten aus Radoboj in Croatien. Novorum Actorum Academiae Caesareae Leopoldino-Carolinae Naturae Curiosorum, 20:399-410. (In German)

Dos Reis, M. and Yang, Z. 2013. The unbearable uncertainty of Bayesian divergence time estimation. Journal of Systematics and Evolution, 51:30-43.

Ducreux, J. L., Hugueney, M., and Truc, G. 1985. La formation des Calcaires et Lignites de Sigonce (Oligocène moyen, bassin de Forcalquier, Alpes-de-HauteProvence): datation à l'aide des mammifères; reconstitution des milieux de dépôts. Geobios, 18:109-114. (In French)

Dumont, H.J., Vanfleteren, J.R., De Jonckheere, J.F., and Weekers, P.H. 2005. Phylogenetic relationships, divergence time estimation, and global biogeographic patterns of calopterygoid damselflies (Odonata, Zygoptera) inferred from ribosomal DNA sequences. Systematic Biology, 54:347-362. 
Dumont, H.J., Vierstraete, A., and Vanfleteren, J.R. 2010. A molecular phylogeny of the Odonata (Insecta). Systematic Entomology, 35:6-18.

Fleck, G. 2011. Phylogenetic affinities of Petaluridae and basal Anisoptera families (Insecta: Odonata). Stuttgarter Beiträge zur Naturkunde A, Neue Serie, 4:83104.

Fleck, G., Bechly, G., Martínez-Delclòs, X., Jarzembowski, E., Coram, R., and Nel, A. 2003. Phylogeny and classification of the Stenophlebioptera (Odonata: Epiproctophora), Annales de la Société entomologique de France: International Journal of Entomology, 39: 55-93.

Fleck, G., Nel, A., Bechly, G., Delclos, X., Jarzembowski, E.A., and Coram, R. 2009. New Lower Cretaceous 'libelluloid' dragonflies (Insecta: Odonata: Cavilabiata) with notes about estimated divergence dates for this group. Palaeodiversity, 1:19-36.

Fleck, G., Nel, A., and Martínez-Delclòs, X. 1999. The oldest record of libellulid dragonflies from the Upper Cretaceous of Kazakhstan (Insecta: Odonata, Anisoptera). Cretaceous Research, 20:655-658.

Fleck, G., Ullrich, B., Brenk, M., Wallnisch, C., Orland, M., Bleidissel, S., and Misof, B. 2008. A phylogeny of anisopterous dragonflies (Insecta, Odonata) using mtRNA genes and mixed nucleotide/doublet models. Journal of Zoological Systematics and Evolutionary Research, 46:310-322.

Garrison, R.W., von Ellenrieder, N., and Louton, J.A. 2006. Dragonfly Genera of the New World: An Illustrated and Annotated Key to the Anisoptera. The Johns Hopkins University Press, Baltimore, Maryland.

Grimaldi, D. 2005. Evolution of the Insects. Cambridge University Press. New York.

Hasegawa, E. and Kasuya, E. 2006. Phylogenetic analysis of the insect order Odonata using $28 \mathrm{~S}$ and $16 \mathrm{~S}$ rDNA sequences: a comparison between data sets with different evolutionary rates. Entomological Science, 9:55-66.

Heer, O. 1849. Die Insektenfauna der Tertiärgebilde von Oeningen und von Radoboj in Croatien. Vol. 2. Heurschrecken, Florfliegen, Alderflügler, Schmetterlinge, und Fliegen. - Engelmann, Leipzig. (in German)

Hovmöller, R. 2006. Molecular Phylogenetics and Taxonomic Issues in Dragonfly Systematics (Insecta: Odonata). Zoologiska institutionen, Stockholm.

Huang, D. and Nel, A. 2007. Oldest 'libelluloid' dragonfly from the Middle Jurassic of China (Odonata: Anisoptera: Cavilabiata). Neues Jahrbuch für Geologie und Paläontologie-Abhandlungen, 246:63-68.

Inoue, J., Donoghue, P.C., and Yang, Z. 2010. The impact of the representation of fossil calibrations on Bayesian estimation of species divergence times. Systematic Biology, 59:74-89.

İslamoğlu, Y., Harzhauser, M., Gross, M., JiménezMoreno, G., Coric, S., Kroh, A., Rögl, F., and van der Made, J. 2010. From Tethys to Eastern Paratethys: Oligocene depositional environments, paleoecology and paleobiogeography of the Thrace Basin (NW Turkey). International Journal of Earth Sciences, 99:183-200.

Jarzembowski, E. and Nel, A. 2002. The earliest damselfly-like insect and the origin of modern dragonflies (Insecta: Odonatoptera: Protozygoptera). Proceedings of the Geologists' Association, 113:165-169.

Joyce, W.G., Parham, J.F., Lyson, T.R., Warnock, R.C., and Donoghue, P.C. 2013. A divergence dating analysis of turtles using fossil calibrations: an example of best practices. Journal of Paleontology, 87:612-634.

Kambhampati, S. and Charlton, R.E. 1999. Phylogenetic relationship among Libellula, Ladona and Plathemis (Odonata: Libellulidae) based on DNA sequence of mitochondrial 16S rRNA gene. Systematic Entomology, 24:37-49.

Kiauta, B. 1969. Croatocordulia Platyptera (Charpentier, 1843) Gen. Nov. iz spodnjega miocena radoboja na hrvatskem (Odonata, Anisoptera, Corduliidae, Corduliinae). Geologija: razprave in poročila, 12:85-90. (In Slovenian)

Letsch, H.O., Greve, C., Kück, P., Fleck, G., Stocsits, R.R., and Misof, B. 2009. Simultaneous alignment and folding of $28 \mathrm{~S}$ rRNA sequences uncovers phylogenetic signal in structure variation. Molecular Phylogenetics and Evolution, 53:758-771.

Lewis, S.E. 1969. Fossil insects of the Latah Formation (Miocene) of eastern Washington and northern Idaho. Northwest Science, 43:99-115.

Lin, Q.B. 1982. Insecta. Palaeontological Atlas of East China, 3:148-155.

Liu, Y., Liu, Y., and Zhang, H. 2006. LA-ICPMS Zircon U$\mathrm{Pb}$ dating in the Jurassic Daohugou Beds and correlative strata in Ningcheng of Inner Mongolia. Acta Geologica Sinica, English Edition, 80:733-742.

Liu, Y.Q., Kuang, H.-W., Jiang, X.-J., Peng, N., Xu, H., and Sun, H.-Y. 2012. Timing of the earliest known feathered dinosaurs and transitional pterosaurs older than the Jehol Biota. Palaeogeography, Palaeoclimatology, Palaeoecology, 323:1-12.

Lohmann, H. 1996. Das phylogenetische System der Anisoptera (Odonata). Entomologische Zeitschrift, 106:209-266. (In German)

Misof, B., Rickert, A.M., Buckley, T.R., Fleck, G., and Sauer, K.P. 2001. Phylogenetic Signal and its Decay in Mitochondrial SSU and LSU rRNA Gene Fragments of Anisoptera. Molecular Biology and Evolution, 18:27-37.

Mlíkovský, J. 1997. Taxonomic identity of Fringilla radoboyensis von Meyer 1865 (Aves) from the middle Miocene of Croatia. Annalen des Naturhistorischen Museums in Wien, Series A, 98:143-149.

Nash, B.P. and Perkins, M.E. 2012. Neogene Fallout Tuffs from the Yellowstone Hotspot in the Columbia Plateau Region, Oregon, Washington and Idaho, USA. PLoS ONE, 7(10):e44205.

Nel, A., Arillo, A., Martínez- Delclòs, X., Paicheler, J.C., and Henrotay, M. 1993. Les "Anisozygoptera" fos- 
siles. Phylogénie et classification (Odonata). Martinia, Special Edition, 3:1-311. (In French)

Nel, A., Bechly, G., Prokop, J., Béthoux, O., and Fleck, G. 2012. Systematics and evolution of Paleozoic and Mesozoic Damselfly-like Odonatoptera of the 'Protozygopteran' grade. Journal of Paleontology, 86:81104.

Nel, A. and Huang, D. 2009. First Chinese Cymatophlebiidae from the Middle Jurassic of Inner Mongolia (Odonata: Anisoptera: Aeshnoptera). Palaeodiversity, 2:199-204.

Nel, A., Marie, V., and Schmeißnerb, S. 2002. Revision of the lower Mesozoic dragonfly family Triassolestidae Tillyard, 1918 (Odonata: Epiproctophora). Annales de Paléontologie, 88:189-215.

Nel, A. and Papazian, M. 1985. Description d'une nouvelle espèce d'odonate fossile du Stampien d'Aix-enProvence (Odonata, Libellulidae). Entomologica Gallica, 1:351-355. (In French)

Nel, A. and Paicheler, J. 1993. Les libellulidae fossiles. Un inventaire critique (Odon., Anisoptera, Libelluloidea). Entomologica Gallica, 4:166-190. (In French)

$\mathrm{Nel}, \mathrm{A}$. and Paicheler, J. 1994. Les Libelluloidea fossiles autres que Libellulidae. Un inventaire critique (Odonata, Corduliidae, Macromiidae, Synthemistidae, Chlorogomphidae et Mesophlebiidae). Nouvelle Revue d'Entomologie, 11:321-334. (In French)

Parham, J.F., Donoghue, P.C., Bell, C.J., Calway, T.D., Head, J.J., Holroyd, P.A., Inoue, J.G., Irmis, R.B., Joyce, W.G., and Ksepka, D.T. 2012. Best practices for justifying fossil calibrations. Systematic Biology, 61:346-359.

Pfau, H.K. 2005. Structure, function and evolution of the 'glans' of the anisopteran vesica spermalis (Odonata). International Journal of Odonatology, 8:259310.

Pritykina, L. 1977. New dragonflies from Lower Cretaceous deposits of Transbaikalia and Mongolia. Sovmestnaâ Sovetsko-Mongol'skaâ Paleontologičeskaâ Ekspeditciâ, Trudy, 4:81-96.

Pritykina, L.N. 1981. Noviye Triasoviye Strekozy Sredney Azii [New Triassic dragonflies from Central Asia]. Trudy Paleontologicheskogo instituta akademii nauk SSSR, 183:5-42. (In Slovenian)

Rehn, A.C. 2003. Phylogenetic analysis of higher-level relationships of Odonata. Systematic Entomology, 28:181-240.

Riek, E.F. 1976. A new collection of insects from the Upper Triassic of South Africa. Annals of the Natal Museum, 22:791-820.

Riek, E.F. and Kukalová-Peck, J. 1984. A new interpretation of dragonfly wing venation based upon early upper Carboniferous fossils from Argentina (Insecta: Odonatoidea) and basic character states in pterygote wings. Canadian Journal of Zoology, 62:1150-1166.

Ris, F. 1910. The identity of two Odonata fossils. Bulletin of the Wisconsin Natural History Society, 8:102-105.

Sauquet, H., Ho, S.Y., Gandolfo, M.A., Jordan, G.J., Wilf, P., Cantrill, D.J., Bayly, M.J., Bromham, L., Brown,
G.K., and Carpenter, R.J. 2012. Testing the impact of calibration on molecular divergence times using a fossil-rich group: the case of Nothofagus (Fagales). Systematic Biology, 61:289-313.

Saux, C., Simon, C., and Spicer, G.S. 2003. Phylogeny of the dragonfly and damselfly order Odonata as inferred by mitochondrial $12 \mathrm{~S}$ ribosomal RNA sequences. Annals of the Entomological Society of America, 96:693-699.

Schweigert, G. 2007. Ammonite biostratigraphy as a tool for dating Upper Jurassic lithographic limestones from South Germany first results and open questions. Neues Jahrbuch für Geologie und Paläontologie-Abhandlungen, 245:117-125.

Scudder, S.H. 1892. Some Insects of Special Interest from Florissant, Colorado, and Other Points in the Tertiaries of Colorado and Utah. Vol. 93. US Government Printing Office, Washignton.

Shcherbakov, D. 2008. On Permian and Triassic insect faunas in relation to biogeography and the PermianTriassic crisis. Paleontological Journal, 42:15-31.

Sinitza, S. 1995. Chernovskii paleontological reserve. Bulletin of the Chita Polytechnic Institute, Jubilee Edition:70-84.

Steininger, F.F., Berggren, W.A., Kent, D.V., Bernor, R.L., Sen, S., and Agusti, J. 1996. Circum-Mediterranean Neogene (Miocene and Pliocene) marine-continental chronologic correlations of European mammal units, Columbia University Academic Commons, http:// hdl.handle.net/10022/AC:P:12443.

Sukatsheva, I. and Vassilenko, D. 2013. New taxa of caddisflies (Insecta, Trichoptera) with reduced forewing venation from the Mesozoic of Asia. Paleontological Journal, 47:77-83.

Tillyard, R.J. 1916. Descriptions of the fossil Insects; Mesozoic and Tertiary Insects of Queensland and New South Wales. Descriptions of the fossil Insects and stratigraphical features. Queensland Geological Survey, 253:11-70.

Tillyard, R.J. 1918. Mesozoic Insects of Queensland. No. 3 Odonata and Protodonata. The Proceedings of the Linnean Society of New South Wales, 43:417-436.

Tillyard, R.J. 1925. The British Liassic Dragonflies (Odonata). British Museum (Natural History), Fossil Insects, 1:1-40.

Trueman, J. 1996. A preliminary cladistic analysis of odonate wing venation. Odonatologica, 25:59-72.

Vasilenko, D. 2005. New Damselflies (Odonata: Synlestidae, Hemiphlebiidae) from the Mesozoic Transbaikalian Locality of Chernovskie Kopi. Paleontological Journal, 39:280-283.

Vernoux, J., Huang, D., Jarzembowski, E.A., and Nel, A. 2010. The Proterogomphidae: a worldwide Mesozoic family of gomphid dragonflies (Odonata: Anisoptera: Gomphides). Cretaceous Research, 31:94-100.

Ware, J., May, M., and Kjer, K. 2007. Phylogeny of the higher Libelluloidea (Anisoptera: Odonata): an exploration of the most speciose superfamily of dragon- 
flies. Molecular Phylogenetics and Evolution, 45:289310.

Ware, J.L. 2008. Molecular and Morphological Systematics of Libelluloidea (Odonata: Anisoptera) and Dictyoptera. Rutgers Univeristy, New Brunswick, New Jersey.

Ware, J.L., Beatty, C.D., Sánchez Herrera, M., Valley, S., Johnson, J., Kerst, C., May, M.L., and Theischinger, G. 2014. The petaltail dragonflies (Odonata: Petaluridae): Mesozoic habitat specialists that survive to the modern day. Journal of Biogeography, 41:1291-1300.

Ware, J.L., Ho, S.Y., and Kjer, K. 2008. Divergence dates of libelluloid dragonflies (Odonata: Anisoptera) estimated from rRNA using paired-site substitution models. Molecular Phylogenetics and Evolution, 47:426432.
Ware, J.L., Simaika, J.P., and Samways, M.J. 2009. Biogeography and divergence time estimation of the relict Cape dragonfly genus Syncordulia: global significance and implications for conservation. Zootaxa, 2216:22-36.

Weber, R. 1968. Die fossile Flora der Rhät-Lias Übergangsschichten von Bayreuth (Oberfranken) unter besonderer Berücksichtigung der Coenologie. Erlanger Geologische Abhandlungen, 72:1-73. (In German)

Zhang, J. 1989. Fossil insects from Shanwang, Shandong, China. Shandong Science and Technology Publishing House, Jinan, China. (In Chinese)

Zhang, J., Sun, B., and Zhang, X. 1994. Miocene insects and spiders from Shanwang, Shandong, China. Shandong Science Press, Beijing, China. (In Chinese with English Summary) 
KOHLI, WARE, \& BECHLY: DRAGONFLY FOSSIL CALIBRATIONS

APPENDIX 1.

The following table shows the Odonata venational terminology and abbreviation that are used in this manuscript. This manuscript follows the Riek and Kukalová-Peck (1984) terminology scheme.

\begin{tabular}{|l|l|}
\hline Costa & $\mathrm{C}$ \\
\hline Subcosta & $\mathrm{ScP}$ \\
\hline Radius anterior & $\mathrm{RA}$ \\
\hline Radius posterior, first branch & $\mathrm{RP}_{1}$ \\
\hline Radius posterior, second branch & $\mathrm{RP}_{2}$ \\
\hline Radius posterior, third branch & $\mathrm{RP}_{3+4}$ \\
\hline Intercalar vein 1 & $\mathrm{IR}_{1}$ \\
\hline Intercalar vein 2 & $\mathrm{IR}_{2}$ \\
\hline Media anterior & $\mathrm{MA}$ \\
\hline Media posterior & $\mathrm{MP}$ \\
\hline Cubitus anterior & $\mathrm{CuA}$ \\
\hline Anal anterior and posterior & $\mathrm{AA} / \mathrm{AP}$ \\
\hline
\end{tabular}

